\title{
Under the Eye of Others (the Socialized Interpretation of Shame in the History of Ethics)
}

\author{
Andrei V. Prokof'ev* \\ Institute of Philosophy, Russian Academy of Sciences \\ Moscow, Russian Federation
}

Received 20.03.2020, received in revised form 04.08.2020, accepted 12.08.2020

\begin{abstract}
The main purpose of the article is to reconstruct the development of a socialized interpretation of shame in the Western philosophical tradition from antiquity up to the $17^{\text {th }}$ century. Along with the standard methods of conducting research in the history of philosophy (critical, comparative, hermeneutical, etc.), the author resorts to a strategy of identifying the historical sources and rudimentary forms of contemporary theoretical approaches to understanding moral phenomena. With regard to shame, there are three such approaches, or three interpretations: socialized (identifying shame with negative feelings about a real or imagined loss of face), anthropological (identifying shame with a painful reaction to the generic imperfection of a person in the sphere of corporeality) and desocialized (identifying shame with negative feelings of an individual generated by the awareness of the worthlessness of his own moral character). Studying the development of each of them requires an understanding of how they historically interacted with each other. The first detailed description of shame from the socialized perspective was proposed by Aristotle. In it, shame appears as a fear of disrepute or suffering from it, that is, a negative feeling that presupposes that other people know that an individual has committed an objectively vicious act or that he does not have some objectively valuable quality. Aristotle viewed shame as a less perfect moral trait than virtue (in contemporary socialized conceptions of shame, guilt is usually its more perfect alternative). Thomas Aquinas relies on the Aristotelian understanding of shame, but: a) connects it with the anthropological interpretation proposed by Augustine, b) makes a special emphasis on the fact that shame is appropriate only in the case of the sinfulness of the act. The early modern socialized conceptions of shame are characterized by a movement from doubt about the reasonableness of this feeling to its partial or complete rehabilitation. At the same time, R. Descartes, B. Spinoza and J. Locke, unlike Aristotle and Thomas, approve of shame not only because it is an imperfect counterpart of virtue, but also in connection with its positive social role (as a means of social discipline and an expression of sociability). Although early modern thinkers discuss moral emotions of self-assessment that are not mediated by the "eye of others" (repentance, remorse), they do not oppose them to shame.
\end{abstract}

\footnotetext{
(C) Siberian Federal University. All rights reserved

* Corresponding author E-mail address: avprok2006@mail.ru ORCID: 0000-0001-5015-8226
} 
Keywords: morality, ethics, shame, socialized interpretation of shame, virtue, guilt, Aristotle, Thomas Aquinas, R. Descartes, B. Spinoza, J. Locke.

Research area: ethics.

Citation: Prokof'ev, A.V. (2020). Under the eye of others (the socialized interpretation of shame in the history of ethics). Soc. Sci., 13(8), 1356-1369. DOI: 10.17516/1997-1370-0646.

\section{Problem statement:}

major contemporary interpretations of shame and their historical roots

Shame is the important psychological mechanism of moral experience fulfilling a double function. It aligns behaviour with moral values and requirements, and it is one of the emotional correlates or one of the forms of negative self-esteem. In the latter case, shame means a specific moral emotion which, along with repentance, guilt, self-disappointment, self-contempt, etc., accompanies the violation of moral requirements and disregard for moral values. In the perspective of ethical theory, this emotion can be viewed as one of the moral sanctions - internal and ideal. Understanding the nature of shame is important both for a general theoretical description of moral experience and for evaluating the particular forms that it takes.

There are several interpretations of shame in contemporary philosophy and human sciences. Empirical studies of psychologists and sociologists as well as phenomenological and conceptual analysis carried out by philosophers, equally contributed to the formation of each of them. This article will focus on one of these interpretations. It identifies shame with a negative emotional reaction of the agent to a real or possible and imagined condemnation of his actions by other people. Such condemnation is a painful blow to a person's reputation, a serious loss of face. Shame, understood in this way, can be expressed in the experience of real disgrace, in the discretion arising from imagining the possible consequences of an action for relations with other people, or even in the vague and unconscious anxiety that accompanies planning and performing an action. But in any of its manifestations, shame turns out to be shame "before someone", it is an experience, the essential characteristic of which is being under the "eye of others" in the words of Agnes Heller. For contemporary versions of this interpretation of shame, guilt is the key alternative to this emotion, or the alternative moral sanction. Guilt is independent of the opinions of other people (autonomous). Typically, this autonomy is seen as the advantage of guilt. Another widely discussed advantage of guilt is its potential independence not only of other people's opinions, but also of the evaluative standards they use. These standards in many cases may be far from the core of moral values and requirements. In what follows, I will call this interpretation of shame socialized ${ }^{1}$.

At least two other interpretations vie with the socialized interpretation of shame. One of them also retains the significance of the "eye of others" (and in this sense is also socialized), but at the same time it is closely tied to human corporeality and sexuality. The openness of some manifestations of corporeality for other people, in the presence of additional conditions, causes intense negative feeling in those who are under the eye of others. This feeling is interpreted by theorists as a reflection of a person's subconscious understanding of his imperfection (the inability to control spontaneous bodily impulses, the immersion of a unique personal being in a unified and unifying world of animality, the insecurity of an embodied individual from objectification by other people). In this understanding of shame, it functions as a sanction of a specific part of morality associated with sexual relations (more broadly, with the regulation of various manifestations of corporeality), but tends to expand to other violations of moral

\footnotetext{
1 In contemporary sociology, this position is most vividly represented by Thomas Scheff (Scheff, 2003), in contemporary philosophy - by Agnes Heller (Heller, 1982) and Cheshire Calhoun (Calhoun, 2004).
} 
norms. The contrast between shame and guilt is not critical in this case. Without a claim on being terminologically precise and given the role that arguments about the imperfection of human nature play for the supporters of this interpretation, I will call it anthropological ${ }^{2}$.

The third interpretation of shame severs the connection of this emotion with the external observation or anticipation of its possibility ("the eye of others"), so I will use the term "desocialized". Its supporters view shame as an emotion of self-assessment that is not limited to any narrow sphere (for example, the sphere of corporeality and sexuality) and can be associated with any violations of moral requirements. Guilt again turns out to be an alternative of shame, however, the border between them runs not along the real or imagined presence / absence of the others, but according to different accents of self-condemnation. Guilt is focused on the moral quality of an action and its consequences (the action is perceived by the agent as transgressive, the consequences - as harmful to others, bringing them pain, suffering, humiliation). Shame is concentrated on the moral quality of the agent's personality: the ashamed person perceives himself as a morally unfit person, devoid of those positive qualities that could support an acceptable level of self-esteem and self-respect. In this interpretation, shame also turns out to be a weak part of the opposition and even more so than in the framework of the socialized interpretation. Unlike guilt, it is destructive both for the personality of the moral agent and for his communication with other people 3 .

Historically, these interpretations developed in parallel and, in the course of their development, interacted with each other in a complex manner. The first two of them took shape

\footnotetext{
2 In contemporary ethics, the interpretation is defended by David Velleman (Velleman, 2001), but if you take a small step back, its elements can be found in the works by Vladimir Soloviev, Max Scheler, Jean-Paul Sartre. For further details, see (Prokof'ev, 2016).

3 In psychological studies, this interpretation is articulated by June Tangney (Tangney, Dearing, 2002), in philosophy - by Julien Deonna, Fabrizio Teroni and Rafaelo Rodogno (Deonna, Teroni, Rodogno). However, in the latter case, the authors argue for the equal importance of shame and guilt for the moral experience. For a general overview of the approach, see (Prokof'ev, 2017).
}

much earlier than the third, but elements of the third interpretation were also present in the history of ideas long before its full articulation. My task in the following sections of the article is to reconstruct the gradual formation of that theoretical image of shame which is concentrated on the damage to reputation and the painful experience of losing face. I will confine myself to the history of Western thought and touch on only three key episodes of this process (descriptions and assessments of shame contained in the writings of Aristotle and The Summa Theologica of Thomas Aquinas as well as the place of shame in early modern typologies of passions). My research will focus on the following issues: how shame was defined, how the causes of shame and typical situations of experiencing shame were characterized, for what reasons shame was considered as such a phenomenon of moral experience that is inferior to some others. At the same time, I will try to find out how the characteristics of shame proposed in the history of philosophy differ from its contemporary descriptions belonging to the same paradigm. I mentioned two other theoretical interpretations of shame not because I plan to systematically reconstruct their history, but because some interesting intersections with them can be found in early socialized conceptions of shame.

\section{Aristotle on shame}

Aristotle used two ancient Greek words aidos and aischyne to denote shame. On Rhetoric uses only the latter, The Nicomachean Ethics contains their combination. The sublimely poetic word aidos denotes guiding and warning feelings, while the prosaic and everyday word aischyne denotes the retrospective emotionally loaded self-assessment. This allowed the author of a special work on honour and shame in ancient literature, Douglas Cairns, to view Aristotle's aischyne and aidos as separate aspects of a holistic moral phenomenon (Cairns 1993: $415)^{4}$. However, in On Rhetoric, aischyne overlaps various functions and aspects of shame being both a restraining (regulating) factor and

\footnotetext{
4 I leave out the richness and specificity of shame-aidos discovered by Cairns, since they are weakly manifested in Aristotle's works.
} 
a negative consequence of vicious or simply unsuccessful behaviour. The unity of aidos and aischyne in The Nicomachean Ethics, and even more so the unity and interconnection of the mental experiences denoted by the word aischyne in On Rhetoric, indicate that a person capable of shame is kept from shameful acts precisely by the fear that their commission will entail unpleasant feelings. This circumstance is decisive for the Aristotelian assessment of shame.

In On Rhetoric, Aristotle defines shame as follows, "Let shame be... a sort of pain and agitation concerning the class of evils, whether present or past or future, that seem to bring a person into disrespect" (Aristotle 2006: 134). The Nicomachean Ethics defines shame-ai$d o s$ as "a kind of fear of dishonour" (Aristotle 2009: 79). Do these definitions unambiguously indicate that shame is mediated by other people's opinions? In principle and abstractly, the preservation of honour, like its loss, can be understood as states that do not depend on the real or imagined assessments of others. In this case, Aristotle, like contemporary proponents of the desocialized interpretation of shame, could regard such assessments only as a factor strengthening negative feelings. Shame, independent of the opinions of others, would have the minimum intensity. Aristotle has a statement that could be considered in this context, "They feel more shame at things done before... people's eyes and in the open; hence, too, the proverb "Shame is in the eyes" (Aristotle, 2006: 132).

However, in general, the Aristotelian understanding of honour is too closely tied to judgements and actions of other people (to the giving of honours or performing actions that dishonour the victim) for shame to be an autonomous experience. Aristotle directly confirms this by introducing an additional definition of this passion when discussing the question before whom people feel shame. It looks like this, "Shame is imagination [phantasia] about a loss of reputation" (Aristotle, 2006: 134). In other words, shame arises when somebody is imagining a situation in which informed and evaluating others are involved. In addition, Aristotle argues that nobody "cares" about someone else's opinion itself, it turns into a prob- lem only when expressed ("no one cares about reputation [in the abstract] but on account of those who hold an opinion of him") (Aristotle 2006: 134) ${ }^{5}$. Accordingly, even if shamefulness of an act is not determined by the opinion of other people, then the feeling of shame, when an agent has committed something actually shameful, is connected precisely with a real or possible assessment on their part.

As for the intensification of shame in the presence of an observer mentioned by Aristotle, it should be understood not in connection with the appearance of an informed and evaluating other (a real or imaginary observer), but in connection with some peculiarities of his awareness of what is happening. Then the formula "before... people's eyes" takes on a literal meaning: shame intensifies when the other observes shameful actions directly, in comparison with those cases when awareness of them is obtained in other ways. This is evidenced by Aristotle's quotation of Kydias who tried to actualize the shame of the Athenians by inviting them to "imagine [all] the Greeks standing around them in a circle, actually seeing and not only later hearing about what they might vote" (Aristotle, 2006: 136). The same intensifying role can be played by the spatial proximity of other people accelerating the spread of information about a shameful action or making such spread inevitable (others "are nearby or are going to learn of it") (Aristotle, 2006: 136)

Discussion about the causes of shame and those before whom people feel shame complements this picture in a significant way. The causes of shame are viewed by Aristotle in an objectivist (Cairns prefers the concept of "intrinsic") perspective. These are actions, personality traits and situations the negative character of which is not constituted by the opinion of others and is not even verified on

\footnotetext{
5 For an indication of the important role of this additional definition, see (Grimaldi, 1980: 115).

6 In this regard, the commentators of Aristotle try to guess what would be a reaction of the Aristotelian agent to his own 'secret crime', a crime that is unknown and cannot become known to others. Versions of the answer are the self-condemnation in the form of a dispassionate judgment (Konstan, 2006: 104) or self-disappointment (Fussi, 2015: 118-119), but not shame.
} 
its basis 7 . They tend to lead to "dishonour and censures," but their shamefulness is a function of their being objectively bad. Thus, the first cause of shame is vicious actions. According to the general formulation, these can be any manifestations of any vices (Aristotle, 2006: 133). Then Aristotle discusses such a cause of shame as an absence of beautiful qualities (not necessarily in their highest manifestations, but at least in those inherent in the circle of people who are equal to the ashamed person). It is noteworthy that the elimination of the cause of shame in this area cannot always be ensured through intelligent choice and deliberate activity (Aristotle, 2006: 133). Finally, shame can be a result of other people's actions that cause a person to endure things that lead to "dishonour and censures," such as sexual violence. This statement also questions the necessary connection between shame and deliberate activity (although the proviso that in such cases shame is appropriate only in the absence of adequate resistance to the shameful actions of the other somewhat closes this gap) (Aristotle 2006: 134).

Moving on to the question of those before whom people feel shame, Aristotle introduces a generalized formulation - before those whose opinion we do not despise (Aristotle, 2006: 134). However, the reasons for our attention to the opinions of various representatives of this broad group are different. There is a reason that is directly related to the objectivity of the causes of shame. People "take account of prudent people as telling the truth, and their elders and educated people are of such a sort". Their opinion is important because they are able to assess the actual shamefulness of an action, trait of character or situation. They can act as a tuning fork. Other reasons are no longer associated with the ability of others to discover and tell "the truth", but with the individual sensitivity of the agent to the judgments of specific people. Such sensitivity is connected with the nature of relations with

\footnotetext{
The Nicomachean Ethics mentions acts that are "disgraceful in their truth" and ... "disgraceful only according to common opinion", and a good man should avoid them both. With this passage in mind, what has been said above applies only to causes of shame, which are "disgraceful in very truth" (Aristotle, 2009: 79).
}

others - the judgments of people from whom a person wants to get something, the judgments of close people, the judgments of his rivals, the judgments of those whom he admires, and those for whom he wants to be an object of admiration, judgments of those who until now did not know anything bad about him, etc. are acutely perceived. Finally, the intensity of shame depends on the influence of the condemning other one on the potential strength and breadth of public condemnation. Someone from this group is inclined more than others to pay attention to the deeds and shortcomings of a person who is ashamed, someone is trying to widely disseminate their judgments about him. These are strict moral judges, people who do not have a condemned flaw, people who are offended by a condemned person, people prone to gossip and slander, comic poets and ridiculers (Aristotle, 2006: 134-135).

Unlike On Rhetoric, The Nicomachean Ethics contains not so much a description of shame as a discussion on its correlation with virtue. The analysis of this correlation leads Aristotle to the conclusion about the intermediate nature of shame. On the one hand, shame is close to virtue, since it is not the same as suffering from pragmatic losses and fear of such losses. Already in On Rhetoric, Aristotle emphasized that the experience of shame is generated by dishonour itself, and not by the consequences of this dishonour (Aristotle, 2006: 134). In The Nicomachean Ethics, on this basis, the thesis grows that the ability to experience shame makes an agent participating in the noble and elevates him above pragmatic motives. Aristotle distinguishes between gently born youths who loved all the beautiful, who can be made to be inspired by virtue through reasoning, and the most people who cannot. The reason is that the majority "do not by nature obey the sense of shame, but only fear, and do not abstain from bad acts because of their baseness but through fear of punishment" (Aristotle, 2009: 199). The same characteristics of shame come to the fore in the discussion of "civic courage", or "the courage of the citizen-soldier", which "is due to virtue; for it is due to shame and to desire of a noble object (i.e. honour) and avoidance of 
disgrace, which is ignoble" (Aristotle, 2009: 52). This courage, although not a true virtue, still resembles it more than the courage of those who are forced to fight by the leaders, since it is not based on fear and the desire to avoid suffering.

However, despite the connection with the noble mediated by honour and dishonour, shame is not a virtue, and a person capable of shame is only "conditionally good" (Aristotle, 2009: 79). The reason is that a person who is ashamed or has a developed sense of shame retains desires that push him to commit shameful acts. They make him someone who is capable of committing a shameful act and always walks along this line. This is confirmed by the retrospective shame that occurs when a shameful act has already been committed (this is where Aristotle uses the word aischyne) (Aristotle, 2009: 79). Only for young people who live by passion and have not yet formed virtues in themselves, shame is a proper feeling because it acts as a protective barrier against committing shameful acts (passion, which temporarily replaces virtue). The discussion of "civic courage" in Magna Moralia further clarifies the relationship between shame and virtue. Although such courage is better than forced courage, it is clearly worse than the courage of the person "who is brave ... owing it to his thinking to be right and who acts bravely whether anyone be present or not" (Aristotle, 1915: 65-66). "Civic courage" is unstable - its owner ceases to be courageous if the shame that depends on the presence of others is removed.

Thus, Aristotle understands shame as a reaction to the judgment of other people or as an anticipation of such a judgment. This reaction is based on an objective foundation: a shameful act or a shameful situation remains shameful even outside the external negative assessment. However, outside of this assessment, they do not cause shame. This conclusion makes the Aristotle's conception related to the contemporary interpretation of shame which consider it a feeling associated with a real or possible loss of reputation, a positive image in the eyes of other people. Some versions of this interpretation emphasize the moral ambivalence of shame. Aristotle also argues that, while having a certain moral significance, shame is not the optimal basis for an ethical life. However, unlike contemporary ethicists, Aristotle's attitude to shame is connected not so much with the fact that shame is not autonomous, that it depends on external factors (this thought, as we have seen, is on the periphery of the Aristotelian thought), as with the fact that shame presupposes a struggle with lingering vicious aspirations, and in this struggle, fear and suffering restraining agents from shameful acts retain their role. On this basis, it can be argued that a more autonomous, purely internal experience of guilt, if Aristotle had an idea of it, would not be something preferable for him. A person capable of experiencing guilt and restraining himself on the basis of this experience would be as far from genuine virtue as the ashamed one. Finally, it is necessary to point out an unexpected structural resemblance of the Aristotelian understanding of shame to its contemporary desosialized interpretation. Aristotle's shame presupposes a direct transition from a violation of a norm to agent's negative assessment of his personality. The ashamed person is not concerned with the consequences of his actions for others, but with respect and self-respect. Thus, the Aristotelian understanding of shame leaves room for an emotion that would focus on consequences, harmful effects, etc., but this space is not filled. Such emotion could be called guilt ${ }^{8}$.

\section{Shame in The Summa Theologica by Thomas Aquinas}

It would seem that the possibility of a purely internal shame in The Summa Theologica is closed by the very definition of this passion proposed during the discussion of fear in $A$ Treatise on the Passions, "shame is not fear of the very act of sin, but of the disgrace or

\footnotetext{
8 David Konstan (Konstan, 2006: 102) and Alessandra Fussi (Fussi, 2015: 128) write about the connection between shame and personality assessment in Aristotle's works, but Konstant specifically emphasizes that the Aristotelian shame does not require from an agent to recognize oneself to be a completely unworthy person and does not block the possibilities to atone for the shameful act in one way or another. For Konstant, the contemporary understanding of guilt is more likely to be dissolved in the Aristotelian shame.
} 
ignominy which arises therefrom, and which is due to an extrinsic cause" (Aquinas, 1914: 481) (in another case, when describing shame, he mentions "the disgrace which damages him in the opinion of others" (Aquinas, 1914: 474). Based on Thomas's definitions, shame needs both planning or the actual commission of an "act of sin" and the condemnation of the act by other people. In this respect, the position of Thomas is opposite to the opinion of John Damascene and Gregory of Nyssa that "shamefacedness is fear of doing a disgraceful deed or of a disgraceful deed done" (Aquinas, 1921: 35).

However, in A Treatise on the Cardinal Virtues, trying to deal with the issue of the relationship between shame and the disgraceful character of action, Thomas offers a subtler analysis of this problem. Here he talks about not one, but two types of shame. Firstly, it is the shame "inherent to vice, which consists in the deformity of a voluntary act" (Aquinas, 1921: 36). Such a feeling is internally contradictory, since an act depended on will alone should not have caused fear and for Thomas fear is part of the very definition of shame. Secondly, it is the shame which "is penal so to speak, and... consists in the reproach that attaches to a person" (Aquinas, 1921: 35). In this case, the reasons for the emergence of fear are understandable - the condemnation from others does not depend entirely on the will of the person capable of shame, it cannot be voluntary overcome by him and at the same time causes him suffering (in other words, it is an "arduous evil"). That is why Thomas considers the second kind of shame to be a genuine shame and returns to the original definition of this passion, which arose in the discussion of fear. At the same time, he enriches it in such a way that shame appears as a fear of "reproach", which in turn is "attestation to a person's defect, especially that which results from sin" (Aquinas, 1921: 38).

However, understanding shame as a form of fear raises an additional problem. Is it capable of embracing all the manifestations of the phenomenon? Thomas directly asks this question, "fear is of the future, as stated above. But shame regards a disgraceful deed already done, as Gregory of Nyssa says" (Aquinas, 1914: 473). In this regard, Thomas introduces an additional distinction. The fear of "the disgrace which damages him in the opinion of others" can be different, "if disgrace is feared in a deed that is yet to be done, there is shamefacedness; if, however, it be in a deed already done, there is shame" (Aquinas, 1914: 474). This is, of course, true: the act performed can leave the agent in limbo over the reactions of other people, in which case it causes fear. But it is impossible to ignore the fact that shame is a reaction not only to possible dishonour, but also to the actual one, and therefore it is not only fear, but also the Aristotelian suffering from disrepute. Answering the question "Is all suffering evil?", Thomas discusses shame in this very vein, as "sorrow or pain on account of this present evil" or "sorrows for the good was lost" (Aquinas, 1914: 449).

For Thomas, the problem of a possible connection of shame not with a shameful act itself, but with what seems shameful to people who condemn the agent, has a noticeably greater significance than for Aristotle. Thomas introduces a psychological explanation for this trend. "In man's opinion" condemnation can extend to "any kind of defect", including poverty, slavery, disrepute (Aquinas, 1921: 35). "In man's opinion" even virtuous deeds can appear vicious. Accordingly, people may be infamous for doing virtuous acts, being scolded for their faith or being forced into menial occupation. In all these cases, notoriety creates an opportunity for experiencing shame. Aristotle does not see any significant difficulty in this and recommends that a "good man" avoids both those acts that are disgraceful in very truth and those that are "disgraceful ... only according to common opinion" (Aristotle, 2009: 79). Thomas argues that "reproach is properly due to vice" and this should be the starting point for the feeling of shame (Aquinas, 1921: 36). If someone dishonours another "on account of virtue", then such ignominy should not cause shame, but contempt (Aquinas 1921: 36). In parallel, the establishment of an unambiguous connection between shame and sin closes the opportunity for justified shame in cases where it is caused by a 
situation created by the other (for example, enslavement or violence on his part) ${ }^{9}$.

Continuing the Aristotelian theme of causes of shame, Thomas, unlike Aristotle, introduces their gradation. Not all vices (sins) are equally shameful for him, and even more, from his point of view, the degree of shamefulness of an act does not in all cases follow its severity ("culpability"). At this point, the socialized interpretation of shame intersects with the one centred on human imperfection and corporeality (I called it "anthropological", but in the historical context it could be called "Augustinian"). From Thomas's point of view, the most shameful is intemperance (elsewhere - "sins of the flesh") (Aquinas, 1921: 37) because "it is about pleasures common to us and the lower animals" (Aquinas, 1921: 26). They "dim the light of reason from which all the clarity and beauty of virtue arises: wherefore these pleasures are described as being most slavish" (Aquinas, 1921: 26). According to Thomas, although spiritual sins are more grievous, they are noticeably less disgraceful than the sins of the flesh (Aquinas, 1921: 37). Thomas also mentions a second selection criterion, which is hardly objective and important only for "man's opinion". Associated with less dishonour are those sins that "connote a certain abundance of some temporal good", such as strength. In this regard, people are more ashamed of cowardice than reckless courage, robbery than theft (Aquinas, 1921: 37).

In discussing another Aristotelian theme "before whom people feel shame" - Thomas offers a clarified classification of persons according to the reasons why the shame in front of them becomes or should become more intense. Aristotle's somewhat chaotic empirical observations acquire rigor and logical order. Firstly, those people are important for shame whose "attestation" of defect is "more weighty" because of its truth. On the part of moral truth, the judgments of those who are distinguished by "the rectitude of judgment" are important,

\footnotetext{
Thomas Ryan suggests that in his description of shame, Thomas managed to find a balance between the perfectionist purpose of shame (a means of avoiding moral mistakes) and the communitarian one (emphasizing the importance of joint practice and the value of the other as a partner in this practice) (Ryan, 2013: 81-83).
}

like it happens "in the case of wise and virtuous men, by whom man is more desirous of being honoured" (Aquinas, 1921: 38). On the part of empirical truth, "the knowledge of the matter attested" is important, that is, awareness of the affairs of the condemned person (this awareness is shown by closely connected people). Secondly, the intensity of shame increases when an agent faces those people whose judgments have the greatest pragmatic effects (such are the judgments of those who can be useful for the ashamed person or can harm him) (Aquinas, 1921: 38).

Finally, Thomas rearranges the emphasis of the Aristotelian solution to the problem of "shame and virtue." Like in Aristotle, shame occupies an intermediate position between vice and virtue. For a person that is vicious or steeped in the sin, the inability to be ashamed is an additional flaw. If he could be ashamed of his deeds, then he would not be so vicious. For a virtuous person, the absence of shame is one of the hallmarks of his virtue. As a virtuous one, he cannot be afraid of committing shameful acts, since the avoidance of shameful acts is completely in his hands. However, Thomas emphasizes, he is "so disposed, that if there were anything disgraceful in him, he would be ashamed of it" (Aquinas, 1921: 41). The ability to be ashamed determines the life of those who are in between these extremes, but not only young men, as mentioned in Aristotle's works, but all "average men". The latter are ashamed because "they have certain love of good, and yet are not altogether free from evil." And also because they are on the way to virtue and shame lays its foundations, which is true at least of the virtue of temperance (Aquinas, 1921: 41) ${ }^{10}$.

\section{Shame in early modern typologies of passions}

As Hannah Dawson shows in her pioneering work Shame in Early Modern Thought: from Sin to Sociability, early modern culture used two concepts of shame. As a starting point for her conclusion, she takes $A$ Christian Diction-

\footnotetext{
${ }^{10}$ See the work of Simo Knuuttila (Knuuttila, 2012) on the relationship between the Thomist theoretical image of shame and its other medieval conceptions.
} 
arie by Thomas Wilson (the $1^{\text {st }}$ edition of 1612), which characterizes the "shame of face" ("an affection which springeth, by reason of some civill dishonesty or filthinesse") and "shame of conscience" ("trouble, and perturbation of minde and conscience, beeing grieved and cast downe at the remembrance of sinne against God"), and traces the use of these meanings of shame in literature and philosophical treatises (mostly English). "Shame of conscience", or, as Dawson herself calls it, "guilt-shame", does not require any external judgements, except for the judgement of God who knows everything and is present everywhere. This shame arises in the course of sinner's turning to himself and is identical to a painful realization of a sin. Dawson records the constant presence of an association between "guilt-shame" and the ideas of imperfection of human nature and original sin in the texts of the $17^{\text {th }}$ century. The metaphors that accompany the discussion of this type of shame often include images related to the shame of nudity (Dawson, 2019: 385). In other words, in this case we are confronted with various elements that will be later included in those contemporary interpretations of shame, which I have labelled "anthropological" and "desocialized". Here the conception of shame by Augustine, which laid the foundation of the anthropological interpretation, is directly reproduced and refracted in different ways. As for the similarity with the desocialized interpretation, they share the claim that shame is part of a person's relationship with himself, that it can be experienced in a complete solitude without even the imaginary presence of other people. At the same time, and this is no longer a similarity, but a difference, we do not see any attempts of early modern authors discussing the so called "guilt-shame" to answer the question what is the difference between shame and guilt or remorse.

An important circumstance is that there are no main philosophical authorities of that era among the authors whose texts Dawson uses as an illustration to the topic of "guiltshame". Michel Montaigne and Blaise Pascal are mentioned only in connection with their general criticism of the dependence of self-esteem on the opinions of others (Dawson, 2019:
386, 388). And only the treatise $O f$ the Law of Nature and Nations by Samuel von Pufendorf really represents the case when in the central philosophical text of that era, shame is seen both in the perspective of autonomous self-esteem, and in the perspective of public condemnation (Dawson, 2019: 387-388). Dawson's examples could have been supplemented with fragments from the works of another early modern titan, Hugo Grotius (Grotius, 2005: 1411), but in general, the mainstream of the Western philosophy of the $17^{\text {th }}$ century reproduced what Dawson calls "reputation-shame" (Dawson, 2019: 389). Major early modern thinkers continued the line of Aristotle and Thomas and introduced new turns in the discussion of problems that had already emerged in antiquity and the Middle Ages. I will illustrate this with an example of three thinkers discussing shame: René Descartes, Benedict Spinoza, and John Locke.

If we compare their definitions of shame, we see an obvious similarity and continuity. Descartes and Spinoza discuss paired affects: pride and shame. Descartes's pride "is a kind of joy based on the love we have for ourselves and resulting from the belief or hope we have of being praised by certain other persons ... Shame, on the other hand, is a kind of sadness based also on self-love, which proceeds from the expectation or fear of being blamed" (Descartes, 1985: 401). The definition of shame from Spinoza's Ethics is as follows: "a sadness accompanied by the idea of some action of ours which we imagine that others blame". If we are faced with pleasure, accompanied by the idea of action, which in our imagination evokes praise from other people, then this is one of the subtypes of pride ("pride as love of esteem (gloria)") (Spinoza, 1994: 193). Locke's definition of shame, which does not correspond to the definition of pride, is "an uneasiness of the mind upon the thought of having done something which is indecent, or will lessen the valued esteem which others have for us" (Locke, 1824a: 219).

Early Modern thinkers following the Aristotelian-Thomistic paradigm of the understanding of shame distinguished it from the feelings of the agent which are directly related to the moral quality of his actions and do not 
depend on the opinions of other people. They are analogous to guilt in the contemporary socialized interpretation of shame. In Descartes's The Passions of the Soul, these are remorse and repentance (Descartes, 1985: 392, 396-397). In Spinoza's Ethics, it is only repentance (Spinoza, 1994: 192). It is noteworthy that both thinkers do not directly oppose repentance and remorse to shame or consider these passions as something superior to shame (this is characteristic of some contemporary socialized conceptions of shame). They also do not criticize the identification of shame with those emotions of self-assessment that are not mediated by the opinion of others (we can find this kind of criticism in The Summa Theologica). This fact is all the more unexpected since, as Dawson shows, such an identification was widespread in early modern culture.

Even if shame is related by Descartes, Spinoza and Locke to something more valuable, then it is not repentance or remorse, but virtue. In this respect, early modern thinkers also follow Aristotle and Thomas. For Descartes, such a correlation is devoid of sharpness and antagonism, since virtue for him does not replace the passions that deserve approval, but cooperates with them (Descartes, 1985: 386). Likewise, in Locke's works, the desire for a good reputation, which is the basis of shame, is something "nearest to" virtue (meaning virtue in the understanding present in the treatise Some Thoughts Concerning Education, that is "the knowledge of a man's duty") (Locke, 1824b: 44). In Spinoza's case, the recognition of the superiority of virtue over shame is accompanied by a sharply negative judgment about the latter. In Ethics, Spinoza does not give a direct assessment of the affect of shame, but instead proposes to carry it out on the model of the criticism of compassion and repentance ${ }^{12}$. This means that, like these two affects, shame is "evil of itself and useless" (Spinoza, 1994: 226). Like compassion, it often misleads the agent about what is good and what is bad

\footnotetext{
11 The concept of shame expressed in this treatise is analyzed by Robert Metcalf (Metcalf: 436-437).

${ }^{12}$ In contrast to criticism and partial rehabilitation of shame, Spinoza's criticism and partial rehabilitation of other affects have been fairly well studied, see (Alanen, 2012; Green, 2016; Soyarslan, 2018).
}

(Spinoza, 1994: 226). Like repentance, it is a senseless suffering because the evil deed that makes us suffer has already been done (Spinoza, 1994: 228). However, all affects, which are passive states, receive a negative assessment in Spinoza. Virtue for Spinoza "is nothing but living according to the guidance of reason", and a person who is submitted to affects "allows himself to be guided by things outside him" (Spinoza, 1994: 219) ${ }^{13}$.

Spinoza's criticism of shame is accompanied by its partial rehabilitation including arguments related to the beneficial social effects of this passion. Such arguments were absent from Aristotle's and Thomas's works. They saw the positive side of shame in the proximity of the states of mind and the behaviour formed on the basis of shame with the states of mind and the behavior of a virtuous person. As a starting point for this rehabilitation, Spinoza uses the fact that "man rarely live from the dictate of reason" and the absence of such guidance often leads to the prevalence of "pride as arrogance" (superbia) and the collapse of social relations. This turns most people into a "terrifying mob", which reduces the chances to "live from the dictate of reason" for both those who belong to the mob and those who successfully resists pride, but, like any person, depends on interaction with others. Fortunately, people have affects that oppose the transformation of society into a mob and, therefore, "bring more advantage than disadvantage". These are humility, repentance, hope and fear. Spinoza writes about them that "since men must sin, they ought rather to sin in that direction". Shame is absent from this listing, however, describing the position of "weak-minded men" that "were all equally proud" and cannot "be united or restrained by any bonds", Spinoza mentions not only that they are not afraid of anything, but also that they are "ashamed of nothing" (Spinoza, 1994: 228).

The same rehabilitative trend can be found in Descartes who also asks the question of whether we have "to rid oneself entirely of these passions [i.e. pride and shame], as the Cynics used to do", and responds negatively

\footnotetext{
13 The normative basis for Spinoza's criticism of affects has been analyzed in detail by Michael LeBuffe (2010: 175-193).
} 
(Descartes, 1985: 401) ${ }^{14}$. But Locke's inquiry in the social roots and functions of shame no longer takes the form of a rehabilitation, since Locke initially does not accuse shame of anything. In An Essay Concerning Human Understanding, the behaviour of a moral agent is not discredited either by its affective basis, or its dependence on sanctions, or the external nature of such sanctions. One of the three key components of the "moral good" called "the law of opinion or reputation" is based on common sensitivity to public opinion (Locke, 1824a: 371) Everyone is inclined to obey this law because everyone is not indifferent to "commendation and discredit", "disgrace and disrepute". Locke evaluates this dependence on someone else's judgements as an extremely positive phenomenon. And even more than that, discussing "the law of opinion or reputation", he eliminates the very basis of the criticism of shame as a phenomenon that is less perfect than virtue because he claims that all standards of vice and virtue are established by the communicating people themselves ("by approbation and dislike they establish amongst themselves what they will call virtue and vice") (Locke, 1824a: $373)^{15}$.

\section{Conclusion}

Thus, the analysis of the discussions of shame from The Nicomachean Ethics, Magna Moralia, and On Rhetoric by Aristotle, The Summa Theologica by Thomas Aquinas, The Passions of the Soul by Descartes, Ethics by Spinoza, An Essay Concerning Human Understanding and Some Thoughts Concerning Education by Locke showed that all of them share the central feature of the socialized interpretation of shame: shame is understood as a form of the emotional moral self-assessment mediated by the opinion of others. These early socialized conceptions of shame, like their contemporary equivalents, perceive shame as not the most

\footnotetext{
14 John Marshall explains Descartes' special attention to factors that form the distorted self-esteem through pride and shame by the fact that the highest virtue of his ethics - generosity - requires evaluating oneself exclusively on the basis of the correct use of free will (Marshall, 1998: 103).

15 Dawson views Locke's concept of shame as a product of the final transition of early modern thought to an analysis of shame from a social perspective (Dawson, 2019: 390).
}

perfect mechanism of moral experience. However, there are some substantial differences between early and contemporary versions of the socialized interpretation of shame.

1. For contemporary theorists, the more perfect moral phenomenon than shame is the other negative emotion of self-assessment guilt. For ancient, medieval, and early Modern thinkers, this place occupied by virtue which allows to avoid any kind of negative emotion of self-assessment.

2. Contemporary socialized conceptions of shame present as its central drawback the fact that shame forces moral agents to restrain themselves only in front of other people. For early socialized conceptions, this accusation is marginal (I have already mentioned Aristotle in this regard, a similar thought appears in $\mathrm{Ap}$ pendix to the $4^{\text {th }}$ part of Spinoza's Ethics (Spinoza, 1994: 228)).

3. Another drawback of shame stressed by contemporary socialized conceptions is that shame depends on the contingent and ever-changing normative standards applied by condemning others. The possibility of this claim is created by Aristotle's objectivist line in understanding causes of shame. But the realization of the possibility was sporadic in ancient, medieval, and early modern ethical thought.

4. The main argument for considering shame a genuinely moral feeling provided by contemporary socialized conceptions is that an ashamed person retains at least part of his autonomy. This feature of shame was recorded by earlier thinkers (Aristotle discussed the capacity of an agent to be ashamed before imagined others and to select persons before whom he feels shame). But the moral status of shame was maintained by them on a different basis shame generates the noble and right behaviour.

5. The other serious argument for considering shame a genuinely moral feeling used by contemporary socialized conceptions is that this feeling reflects the natural sociability of humans and belonging of every moral agent to various communities ${ }^{16}$. Early socialized con-

\footnotetext{
${ }^{16}$ Cheshire Calhoun (2004) develops this idea in contemporary ethics. For more on the role of sociability in early modern philosophy, see: (Apressyan, 2019).
} 
ceptions of shame differ in this respect. Stressing the connection of shame with social disci- pline and sociability is typical only for early modern thinkers.

\section{References}

Alanen, L. (2012). Spinoza on Passions and Self-knowledge: The Case of Pride. In Emotion and Cognitice Life in Medieval and Early Modern Philosophy. Oxford: Oxford University Press, 234-254.

Apressyan, R.G. (2019). Problema sotsiabel'nosti v moral'noi filososii rannego Novogo vremeni [The Issue of Sociability in the Early Modern Philosophy]. In Filosofskie nauki [Russian Journal of Philosophical Sciences], 62 (10), 7-24.

Aquinas, Thomas St. (1914). The Summa Theologica. Part II (First Part). QQ. I-XLVIII. London, R. \& T. Washbourne, LTD, $538 \mathrm{p}$.

Aquinas, Thomas St. (1921). The Summa Theologica. Second Part of the Second Part. QQ. CXLI-CLXX. London, Burnes Oates \& Washbourne, LTD, $315 \mathrm{p}$.

Aristotle (1915). Magna Moralia. In Works of Aristotle. Oxford: Clarendon Press, 27-127.

Aristotle (2006). On Rhetoric: A Theory of Civic Discourse. Oxford: Oxford University Press, 2009, $337 \mathrm{p}$.

Aristotle (2009). The Nicomachean Ethics. Oxford: Oxford University Press, 2009, 277 p.

Cairns, D. (1993). Aidos: The Psychology and Ethics of Honour and in Ancient Greek Literature. Oxford: Clarendon Press, $474 \mathrm{p}$.

Calhoun, C. (2004). An Apology for Moral Shame. In Journal of Political Philosophy, 12 (2), 127-146.

Dawson, H. (2019). Shame in Early Modern Thought: from Sin to Sociability. In History of European Ideas, 45 (3), 377-398.

Deonna, J.A., Rodogno, R., Teroni, F. (2012). In Defence of Shame: The Faces of an Emotion. New York: Oxford University Press, $268 \mathrm{p}$.

Descartes, R. (1985). The Passions of the Soul. In The Philosophical Writings of Descartes. Cambridge: Cambridge University Press, 1, 325-404

Fussi, A. (2015). Aristotle on Shame. In Ancient Philosophy, 35(1), 113-135.

Green, K. (2016). Spinoza on Self-Hatred. In Iyyun: The Jerusalem Philosophical Quarterly, 65, 73-95.

Grimaldi, W.M.A. (1980). Aristotle, Rhetoric: A Commentary, Volume 2. Fordham: Fordham University Press, 1980, $362 \mathrm{p}$.

Grotius, Hugo. (2005). The Rights of War and Peace. Indianapolis: Liberty Fund, 1990 p.

Heller, A. (1982). The Power of Shame. In Dialectical Anthropology, 6 (3), 215-228.

Knuuttila, S. (2012). The Emotion of Shame in Medieval Philosophy. In SpazioFilosofico, 5, 2012, 243-249.

Konstan, D. (2006). The Emotions of the Ancient Greeks: Studies in Aristotle and Classical Literature. Toronto: University of Toronto Press, $428 \mathrm{p}$.

LeBuffe, M. (2010). From Bondage to Freedom: Spinoza on Human Excellence. Oxford: Oxford University Press, $253 \mathrm{p}$.

Locke, J. (1824). An Essay Concerning Human Understanding (Books I-III). In The Works of John Locke in Nine Volumes. London: Rivington, 1, 1-511.

Locke, J. (1824). Some Thoughts Concerning Education. In The Works of John Locke in Nine Volumes. London: Rivington, 8, 1-211.

Marshall, J. (1998). Descartes's Moral Theory. Ithaca: Cornell University Press, 169 p.

Metcalf, R. (2004). Balancing the Senses of Shame and Humour. In Journal of Social Philosophy, 35 (3), 432-447.

Prokof'ev, A. (2017). Styd bez «Oka Drugikh» (eticheskii analiz desotsializirovannoi kontseptsii styda) [Shame without the 'Eye of Others': An Ethical Analysis of the Desocialized Conception of Shame]. In Chelovek [Human Being], 4, 38-51. 
Prokof'ev, A. (2016). Moral' i polovoi styd (Vladimir Solov'ev - Maks Sheler - Devid Velleman) [Morality and Sexual Shame (Vladimir Soloviev - Max Scheler - David Velleman)]. In Filosofiia i kul'tura [Philosophy and Culture], 7, 889-899.

Ryan, T. (2013). Aquinas on Shame: A Contemporary Interchange. In Aquinas, Education and the East. New York: Springer, 73-100.

Scheff, T.J. (2003). Shame in Self and Society. In Symbolic Interaction, 26 (2), 239-262.

Soyarslan, S. (2018). Spinoza's Critique of Humility in the Ethics. In The Southern Journal of Philosophy, 56(3), 342-364.

Spinoza, Benedictus de (1994). Ethics. In A Spinoza Reader: The Ethics and Other Works. Princeton: Princeton University Press, 85-276.

Tangney, J.P., Dearing, R.L. (2002). Shame and Guilt. New York: Guilford Press, 272 p.

Velleman, D.J. (2001). The Genesis of Shame. In Philosophy \& Public Affairs, 30 (1), $27-52$.

\title{
Под оком других \\ (социализированная интерпретация стыда в истории этической мысли)
}

\author{
A.В. Прокофьев \\ Институт философии РАН \\ Российская Федерачия, Москва
}

\begin{tabular}{l}
\hline Аннотация. Основная цель статьи состоит в том, чтобы реконструировать разви- \\
тие социализированной интерпретации стыда в западной философской традиции \\
с античнсти до XVII в. Наряду со стандартными методами проведения историко- \\
философского исследования (критическим, сравнительным, герменевтическим \\
и т. д.) автор прибегает к стратегии выявления исторических истоков и рудимен- \\
тарных форм бытования современных теоретических подходов к пониманию тех \\
или иных феноменов. В отношении стыда существуют три таких подхода, или три \\
интерпретации: социализированная (отождествляющая стыд с негативными пере- \\
живаниями по поводу реальной или воображаемой потери лица), антропологиче- \\
ская (отождествляющая стыд с болезненной реакцией на родовое несовершенство \\
человека в сфере телесности) и десоциализированная (отождествляюая стыд с не- \\
гативными переживаниями индивида, которые порождены осознанием негодности \\
собственного морального характера). Анализ формирования каждой из них требу- \\
ет понимания того, как они исторически взаимодействовали между собой. Первое \\
развернутое описание стыда в социализированной перспективе было предложено \\
Аристотелем. В нем стыд выступает как страх бесчестья или страдание от него, \\
то есть как негативное переживание, которое предполагает, что другие люди знают \\
о совершении индивидом объективно порочного действия или об отсутствии у него \\
какого-то объективно положительного качества. Аристотель рассматривал стыд \\
как менее совершенную моральную способность, чем добродетель (в современных \\
социализированных концепциях стыда его более совершенной альтернативой вы- \\
ступает обычно вина). Фома Аквинский опирается на аристотелевское понимание \\
стыда, но: а) соединяет его с антропологической интерпретацией, предложенной \\
Августином, б) делает специальный акцент на том, что стыд уместен исключи- \\
тельно в случае греховности деяния. Для новоевропейских социализированных
\end{tabular} 
концепций стыда характерно движение от сомнения в разумной обоснованности этого чувства к его частичной реабилитации. При этом Р. Декарт, Б. Спиноза и Дж. Локк, в отличие от Аристотеля и Фомы, одобряют стыд не только потому, что он является несовершенным двойником добродетели, но и в связи с его положительной общественной ролью (как средство дисциплинирования и выражение социабельности). Хотя новоевропейские мыслители обсуждают моральные эмоции самооценки, не опосредованные «оком других» (раскаяние, угрызения совести), они не противопоставляют их стыду.

Ключевые слова: мораль, этика, стыд, социализированная интерпретация стыда, добродетель, вина, Аристотель, Фома Аквинский, Р. Декарт, Б. Спиноза, Дж. Локк.

Научная специальность: 09.00.05 - этика. 